\title{
Effect of Chitosan Coating on Preserving Character of Post-Harvest Fruit and Vegetable: A Review

\author{
Yu Youwei ${ }^{1,2}$ and Ren Yinzhe ${ }^{1 *}$
}

${ }^{1}$ College of chemistry and materials, Shanxi Normal University, Linfen 041004, China

${ }^{2}$ College of Engineering, Shanxi Normal University, Linfen 041004, China

\begin{abstract}
Chitosan coating as an edible substance has been applied in the preservation of fresh fruit, vegetable or their fresh-cut materials. After coating with chitosan on the surface of post-harvest fruit and vegetable, the respiration rate and weight loss rate are restrained, and higher firmness is remained. Meanwhile, the activities of protective enzymes are maintained higher level, and the cell membrane can keep relatively intact. Furthermore, chitosan coating has certain preventive effect against microbes and can reduce decay. Since the storage condition of post-harvest fruit and vegetable is improved, more nutrients are also reserved. Chitosan coating would probably have wide prospect in the preservation of post-harvest fruits and vegetables in the future.
\end{abstract}

Keywords: Chitosan; Coating; Fruit; Vegetable; Preserving character

\section{Introduction}

Fruits and vegetables are rich in nutrients, such as minerals, vitamins, amino acids, carbohydrate, and so on, and have good flavor including sweet, sour, or particular odor. In addition, many fruits, such as golden pear and red apple, are crisp and juicy as well as colorful. Post-harvest fruits and vegetables are living organism, still undertaking metabolism ceaselessly [1]. They shrink and lose luster because of water transpiration, and the nutrients are also consumed owing to respiration during the storage time. Meanwhile, post-harvest fruit and vegetable easily rot owing to the activity of spoilage microorganism [2]. Now, many methods including low temperature, controlled atmosphere storage and edible coating are applied to maintain the quality and extend the shelf life of post-harvest fruit and vegetable [3-5].

Chitosan, a linear polysaccharide consisting of $(1,4)$-linked 2 -amino-deoxy- $\beta$-D-glucan, is a deacetylated derivative of chitin, which is the second most abundant polysaccharide found in nature after cellulose. Chitosan has been found to be non-toxic, biodegradable, biofunctional, and biocompatible, and is reported by several researchers to have strong antimicrobial and antifungal activities [6]. It can form a film on fruit and vegetable surfaces and reduces respiration adjusting the permeability of carbon dioxide and oxygen. The group of chitosan may also restrain the propagation of harmful germs, thus effectively controlling fruit decay. Considering these superior properties of chitosan, it has been successfully used in many postharvested fruits, vegetables or their fresh-cut samples [7] (Figure 1).

Nowadays many reports involving chitosan coating mostly focus on the varieties of fruit and vegetable or compound coating based on chitosan $[8,9]$. However, as for the preserving characteristics, such as physiological quality, biochemical parameters, microbial indicators and nutrient status of post-harvest fruit and vegetable, there is no detailed report at present. This review attempts to summarize the effect of chitosan coatings on preserving character of post-harvest fruit and vegetable. We expect that this review will provide insights for researchers working on post-harvest preservation.

\section{Effect of chitosan coating on physiological quality}

Weight loss: The reason causing weight loss of post-harvest fruits and vegetables includes transpiration and the substrate consumption

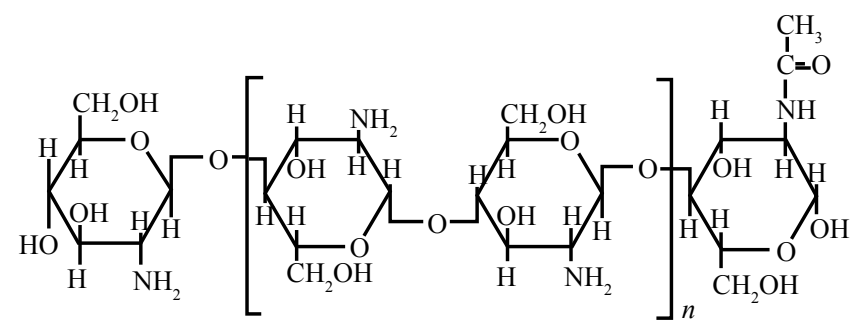

Figure 1: The structure of chitosan.

of respiration. And water loss is about $80 \%$ of the total weight loss. After water loss, the texture of fruits and vegetables turn soft from crisp. Their taste decreases, and their resistant ability against all kinds of physical and microbial disease also come down [10]. After coating with chitosan on the surface of fruit and vegetable, more water in the tissue of fruit and vegetable were reserved $[11,12]$. Thus, good character and commercial value of post-harvest fruit and vegetable are effectively maintained.

Respiration: Aerobic respiration is necessary for post-harvest fruits and vegetables to maintain their own character. The nutrients are consumed as respiration substrate. With the decrease in nutrients, the nutritious and commercial value decline accordingly. Properly restraining the respiration rate is beneficial to prolong the shelf life of post-harvest fruit and vegetable [13]. Research shows that respiration rate can be slowed down in relatively low ratio of oxygen and dioxide carbonate. After coating on the surface of fruits and vegetables, the permeability that the oxygen of air enters the tissue of fruit and

*Corresponding author: Ren Yinzhe, College of chemistry and materials, Shanxi Normal University, Linfen 041004, China, Tel: +86 357 2051192; E-mail: sxnunew@163.com

Received July 08, 2013; Accepted August 18, 2013; Published August 25, 2013

Citation: Youwei Y, Yinzhe R (2013) Effect of Chitosan Coating on Preserving Character of Post-Harvest Fruit and Vegetable: A Review. J Food Process Technol 4: 254. doi:10.4172/2157-7110.1000254

Copyright: ( 2013 Youwei Y, et al. This is an open-access article distributed under the terms of the Creative Commons Attribution License, which permits unrestricted use, distribution, and reproduction in any medium, provided the original author and source are credited. 
vegetable or dioxide carbonate generated through respiration gives off towards air, can be adjusted. Thus, the respiratory rate decreased [14]. However, the thickness of chitosan coating needs to be suitable. The permeability cannot be effectively adjusted if the coating is too thin, or the dioxide carbonate was accumulated if the coating is much thicker. And high concentration of dioxide carbonate may cause anaerobic respiration, which generates ethanol to poison the post-harvest fruits and vegetables.

Firmness: Crisp, related with firmness, is an important sensory characteristic of fresh fruit and vegetable. Once post-harvest fruits become soft during storage time, their crisp characteristic gradually decreases and then disappears. During the storage period of fresh fruits and vegetables, their firmness will decrease owing to water evaporation, pectin degradation, nutrient consumption, and so on [15]. Chitosan coating can restrain the transpiration, and then more water is reserved. Thus, the cell of fruit and vegetable maintains the larger swelling pressure and shows higher firmness. So chitosan coating could reduce the firmness decrease of post-harvest fruit and vegetable to some extent [16].

\section{Effect of chitosan coating on protective enzymes}

The environment condition of the post-harvest fruits and vegetables has changed, and the reactive oxygen in their tissue is easy to accumulate. Reactive oxygen has stronger oxidizing ability and can deeply harm the cell membrane of fruits and vegetables. It is usually eliminated by protective enzymes, such as superoxide dismutase (SOD), peroxidase (POD), and catalase (CAT). In addition, the antioxidant substance also contributes to eliminate reactive oxygen. SOD catalyzes exclusively $\mathrm{O}^{2-}$ into non-toxic $\mathrm{O}_{2}$ and low toxic $\mathrm{H}_{2} \mathrm{O}_{2}$ through dismutation reaction. Further, $\mathrm{H}_{2} \mathrm{O}_{2}$ will be catalyzed into $\mathrm{H}_{2} \mathrm{O}$ and $\mathrm{O}_{2}$ by CAT or POD [17-19]. After coating with chitosan, the protective enzymes of the fruit and vegetable usually maintain high activities, and the free radical such as reactive oxygen in the cell of fruit and vegetable will be rapidly eliminated. Thus, the senescence of postharvest fruit and vegetable was postponed [20].

\section{Effect of chitosan coating on cell membrane}

The cell membrane plays an important role in maintaining cell structure and function of the post-harvest fruits and vegetables. Two key indicators of cell membrane integrity are permeability and malonaldehyde (MDA) content. During the storage time, much free radical in the cell accumulates and harms to cell membrane owning to the destruction of equilibrium mechanism between production and elimination of the radical [21]. Lipid peroxidation is an oxidation process of unsaturated fatty acid through free radical action. The reaction produces lipid peroxide that is poisonous to cell. MDA, one of final products in lipid peroxidation reaction, can severely harm cell membrane. MDA content reflects the active status of free radical of post-harvest fruit and vegetable. The more the MDA content is, the higher the level of free radical such as $\cdot \mathrm{OH}$ and $\mathrm{O}^{2-}[22]$. The cell membrane permeability increases once being damaged, causing the electrolyte leakage rate to increase [23]. After coating with chitosan, the increase of the cell membrane permeability and MDA content can be restrained, and the cell membrane of post-harvest fruit and vegetable may maximally execute normal physiological function.

\section{Effect of chitosan coating on spoilage microorganisms}

The post-harvest fruits and vegetables are vulnerable by all kinds of spoilage microorganisms, and lead to rot. Usually the decay incidence of fruit and vegetable indicates the invasion of microbes. After chitosan coating, the chance for microbes to contact fruits and vegetables has been reduced, thus making fruits free from microbe's invasions [24]. Meanwhile, the amino of chitosan has bacteriostatic effect and can reduce the number of microbes [25]. Furthermore, other factors including decreasing respiration rate, maintaining the protective enzymes higher activities, and making cell membrane integrity, comprehensively strengthen the ability of fruits to defend the microbe. Even if the coated fruit and vegetable is infected, disease incidence is greatly reduced. So the decay incidence of post-harvest fruits and vegetables coated with chitosan shows a downtrend [26].

\section{Effect of chitosan coating on nutrients}

There are many factors leading the nutrients of post-harvest fruit and vegetable to decrease. Saccharide, fat and soluble protein may degrade because of respiration; polyphenol, vitamin $c$ and flavone may serve as antioxidant and participate to eliminate all kinds of free radicals during preservation; some of nutrients decrease owing to pathogenic bacteria activity [27]. After coating with chitosan on the surface of fruit and vegetable, respiration rate decreased, free radicals reduce, and the disease resistance increases. Thus, many nutrients are preserved in maximum [28].

\section{Conclusion}

Chitosan coating has wide application value in fresh fruit, vegetable or their fresh-cut materials. After chitosan coating, the respiration rate and weight loss rate is restrained, and higher firmness is remained. Meanwhile, the activities of protective enzymes are maintained higher level, and the cell membrane can keep relatively intact. Furthermore, chitosan coating had certain preventive effect against microbes and may reduce decay. Since the storage condition of fruit and vegetable is improved, more nutrients are also reserved. Chitosan coating would probably have wide prospect in the preservation of post-harvest fruits and vegetables in the future.

\section{Acknowledgements}

This work was supported by Program for the Innovative Talents of Higher Learning Institutions of Shanxi (2012), and was also supported by project of the Natural Science Foundation of Shanxi Normal University under grant no. ZR1311.

\section{References}

1. Gianfranco R, Ozgur AK, Joseph LS (2007) Combination of chitosan and ethanol to control postharvest gray mold of table grapes. Postharvest Biol Tec 45: $134-140$.

2. Zhang SY, Yu YW, Xiao CY, Wang X, Tian Y (2013) Effect of carbon monoxide on browning of fresh-cut lotus root slice in relation to phenolic metabolism. Food Sci Technol-LEB 53: 555-559.

3. Stefano G, Elena B, Ilaria B, Carnevali F, Gessa CE, et al. (2009) Respiration, hydrogen peroxide levels and antioxidant enzyme activities during cold storage of zucchini squash fruit. Postharvest Biol Tec 52: 16-23.

4. Tian S, Xu Y, Jiang A, Gong Q (2002) Physiological and quality responses of longan fruit to high $\mathrm{O}_{2}$ or high $\mathrm{CO}_{2}$ atmospheres in storage. Postharvest Biol Tec 24: 335-340.

5. Ren YZ, Zhang SY (2013) Effect of Carboxymethyl Cellulose and Alginate Coating Combined with Brewer Yeast on Postharvest Grape Preservation. ISRN Agronomy

6. Majeti NV, Ravi K (2000) A review of chitin and chitosan applications. React Funct Polym 46: 1-27.

7. Mohammed A (2010) Chitosan application for active bio-based films production and potential in the food industry: Review. Food Sci Technol-LEB 43: 837-842.

8. Riccardo AA, Muzzarelli JB, Diederick M, Manno N, DeMarchis M, et al. (2012) Current views on fungal chitin/chitosan, human chitinases, food preservation, glucans, pectins and inulin: A tribute to Henri Braconnot, precursor of the carbohydrate polymers science, on the chitin bicentennial. Carbohyd Polym 87: 995-1012. 
Citation: Youwei Y, Yinzhe R (2013) Effect of Chitosan Coating on Preserving Character of Post-Harvest Fruit and Vegetable: A Review. J Food Process Technol 4: 254. doi:10.4172/2157-7110.1000254

9. Jianglian D, Shaoying Z (2013) Application of Chitosan Based Coating in Fruit and Vegetable Preservation: A Review. J Food Process Technol 4: 227.

10. Velickova E, Winkelhausen E, Kuzmanova S, Alves VD, Moldão-Martins M (2013) Impact of chitosan-beeswax edible coatings on the quality of fresh strawberries (Fragaria ananassa cv Camarosa) under commercial storage conditions. Food Sci Technol-LEB 52: 80-92.

11. Zhong QP, Xia WS (2007) Effect of 1-methylcyclopropene and/or chitosan coating treatments on storage life and quality maintenance of Indian jujube fruit. Food Sci Technol-LEB 40: 404-411.

12. Gao P, Zhu Z, Zhang P (2013) Effects of chitosan-glucose complex coating on postharvest quality and shelf life of table grapes. Carbohyd Polym 95: 371-378.

13. Perdones A, Sánchez-González L, Chiralt A, Vargas M (2012) Effect of chitosan-lemon essential oil coatings on storage-keeping quality of strawberry. Postharvest Biol Tec 70: 32-41.

14. Lin B, Du Y, Liang X, Wang XY, Wang X, et al. (2011) Effect of chitosan coating on respiratory behavior and quality of stored litchi under ambient temperature. J Food Eng 102: 94-99.

15. Qi HP, Hu W, Jiang A, Tian M, Li Y (2011) Extending shelf-life of Fresh-cut 'Fuji' apples with chitosan-coatings. Innovative Food Science and Emerging Technologies 12: 62-66.

16. Xiao Z, Luo Y, Luo YG, Wang Q (2011) Combined effects of sodium chlorite dip treatment and chitosan coatings on the quality of fresh-cut d'Anjou pears. Postharvest Biol Tec 62: 319-326.

17. Katharina FP, Bernard AG, Ederlinda CP, Kiefer S, Soja G, et al. (2002) Free radicals in the fruit of three strawberry cultivars exposed to drought stress in the field. Plant Physiol Bioch 40: 709-717.

18. Isamah GK, Asagba SO, Thomas AE (2000) Lipid peroxidation, o-diphenolase, superoxide dismutase and catalase profile along the three physiological regions of Dioscorea rotundata Poir cv Omi. Food Chem 69: 1-4.
19. Serap D, Pınar T, Mehmet D, Arslan O, Alkan M (2007) Variations of peroxidase activity among Salvia species. J Food Eng 79: 375-382.

20. Hong K, Xie J, Zhang L, Sun D, Gong D (2012) Effects of chitosan coating on postharvest life and quality of guava (Psidium guajava L.) fruit during cold storage. Sci Hortic-Amsterdam 144: 172-178.

21. Shi S, Wang W, Liu L, Wu S, Wei S, et al. (2013) Effect of chitosan/nano-silica coating on the physicochemical characteristics of longan fruit under ambient temperature. J Food Eng 118: 125-131.

22. Long J, Wang X, Gao H, Liu Z, Liu C, et al. (2006) Malonaldehyde acts as a mitochondrial toxin: Inhibitory effects on respiratory function and enzyme activities in isolated rat liver mitochondria. Life Sci 79: 1466-1472.

23. Antunes MDC, Dandlen S, Cavaco AM, Miguel G (2010) Effects of postharvest application of 1-MCP and postcutting dip treatment on the quality and nutritional properties of fresh-cut kiwifruit. J Agric Food Chem 58: 6173-6181.

24. Akbudak N, Tezcan H, Akbudak B, Seniz V (2006) The effect of harpin protein on plant growth parameters, leaf chlorophyll, leaf colour and percentage rotten fruit of pepper plants inoculated with Botrytis cinerea. Sci Hortic-Amsterdam 109: 107-112.

25. Moreira RM, Sara IR, Alejandra P (2011) Effectiveness of chitosan edible coatings to improve microbiological and sensory quality of fresh cut broccoli. Food Sci Technol-Leb 44: 2335-2341.

26. Jiang T, Feng L, Li J (2012) Changes in microbial and postharvest quality of shiitake mushroom (Lentinus edodes) treated with chitosan-glucose complex coating under cold storage. Food Chem 131: 780-786.

27. Yu Y, Zhang S, Ren Y, Li H, Zhang X, et al. (2012) Jujube preservation using chitosan film with nano-silicon dioxide. J Food Eng 113: 408-414.

28. Wang SY, Gao H (2013) Effect of chitosan-based edible coating on antioxidants antioxidant enzyme system, and postharvest fruit quality of strawberries (Fragaria $x$ aranassa Duch.). Food Sci Technol-LEB 52: 71-79. 